\title{
Unlocked Doors: Geoffrey Chaucer's Writing-Rooms and Elizabeth Chaucer's Nunnery
}

In A Room of One's Own, Virginia Woolf asserts that, "a lock on the door means the power to think for oneself" as part of her powerful argument that "a woman must have money and a room of her own if she is to write fiction." ${ }^{1}$ Literal physical separation from others is connected with mental independence. Demonstrating a similar understanding of the parallels between the self and the room, Lakoff and Johnson argue that "container" metaphors are ontological. They write that people are "bounded and set off from the rest of the world by the surface of our skin" and that: "Rooms and houses are obvious containers. Moving from room to room is moving from one container to another."2 But all of these twentieth-century authors make certain assumptions both about the material conditions in which people live and about how personal space, privacy, and indeed the body and mind themselves are conceptualized. Our skin does not actually separate us from the world; through its openings and through our senses it connects us with the world. ${ }^{3}$ People do not always live in rooms and houses, and if they do, those rooms are sometimes not private spaces or are divided from other spaces by curtains rather than locks. The metaphors we live by are not the same in all places or times. As Matthew Boyd Goldie writes in his introduction to this essay cluster, "in other times and places, space itself can be different." 4 An exploration of the rooms that Chaucer imagined and of the structures his daughter inhabited illustrates the openness and flexibility of the spaces of later medieval London.

Issues relating to privacy came under particular pressure at precisely the time that Chaucer lived and wrote. Architectural and lifestyle changes across the thirteenth and fourteenth centuries point to increased interest in private and semi-private spaces; at the same time comments about these changes reveal widespread anxiety. ${ }^{5}$ Woolf quotes James Austen-Leigh's comment that Jane

\footnotetext{
1 Virginia Woolf, A Room of One's Own (Oxford: OUP, 1992), 139; 4.

2 George Lakoff and Mark Johnson, Metaphors We Live By (Chicago: University of Chicago Press, 1980), 29-30).

${ }^{3}$ Claudia Benthien, Skin: On the Cultural Border Between Self and World (Columbia University Press: 2004).

${ }^{4}$ Matthew Boyd Goldie, 'Spatial History, Estres, Edges, and Contents.'

${ }^{5}$ Langland criticizes the fashion for the nobility to eat in chambers or parlours rather than halls in Piers Plowman X: 96-102. See also Chris Given Wilson, The Royal Household and the King's Affinity: Service, Politics, and Finance in England, 1360-1413 (New Haven: Yale University Press, 1986), 29, and Richard Firth Green, Poets and Princepleasers: Literature and the English Court in
} 
Austen's achievements were particularly surprising for "she had no separate study to repair to" and instead had to write in the general sitting room. ${ }^{6}$ But Austen-Leigh and Woolf's implication - that spatial privacy is a vital condition for creative freedom - is historically contingent. Post-Enlightenment understandings of creativity, originality, and genius are very different from earlier ideas about authorship and the process of poetic making. In the later fourteenth century, the privacy afforded by a study was not necessarily seen as desirable or creatively productive. Chaucer, in fact, is particularly interested in porous, open, interconnected images of the self. ${ }^{7}$ Investigating various London spaces encourages an understanding of rooms and institutions that were at once semi-public and semi-private, threshold spaces that eschewed both complete openness and locked-in privacy. Such spaces were somewhat similar to the Italian loggia or portico in the later-medieval period, "structures intermediate between domestic and public space." 8 In this short essay, I'm going to explore later-medieval London living and poetic production by looking both at some scenes of reading and writing from Chaucer's poems and at some of the London spaces that Chaucer knew, especially the rooms which Chaucer's daughter Elizabeth inhabited between 1377 and 1381.

\section{A Room of One's Own}

When Chaucer returned to London in 1374 to take up his job at the customs' house, he returned to a building site. As London recovered after the second wave of the plague in the late 1360s, it entered into a period of redevelopment. In particular, people were building up, adding storeys to their houses to increase and vary their living space, and thus adding to the crowded feeling of London's

the Late Middle Ages (Toronto: University of Toronto Press, 1980), 35-37. For architectural changes in royal palaces at this time see Christopher Wilson, "The Royal Lodgings of Edward III at Windsor: Form, Function, Representation" in Windsor: Medieval Archaeology, Art, and Architecture of the Thames Valley, ed. Laurence Keen and Eileen Scarff (Leeds: British Archaeological Association, 2002), 15-94.

${ }^{6}$ A Room of One's Own, 86.

7 I discuss this in detail in Marion Turner, "Chaucer" in Oxford Handbooks Online, ed. James Simpson (Oxford: OUP, 2015):

http://www.oxfordhandbooks.com/view/10.1093/oxfordhb/9780199935338.001.0001/oxford hb-9780199935338-e-58.

8 Charles Burroughs, "Spaces of Arbitration and the Organization of Space in Late Medieval Italian Cities," in Barbara Hanawalt and Michal Kobialka (Ed.), Medieval Practices of Space (Minneapolis: University of Minnesota Press, 2000), 64-100, 66. 
narrow streets. ${ }^{9}$ The interiors of these houses meanwhile offered more opportunities for demarcating space and for private or semi-private chambers, part of a general trend towards living in less communal or public ways, a trend that continued to develop in the fifteenth century. ${ }^{10}$ Urban dwellers, such as merchants, were increasingly interested in domesticity and interior design; they bought cushions and tapestries, and retreated to semi-private / semi-public rooms. ${ }^{11}$ During Chaucer's tenure the customs house was being developed and built; it was also being diversified. John Churchman's extension comprised: “a small chamber for a latrine and a solar over the counting-house 38 feet by $21 \frac{1}{2}$ broad, containing two chambers and a garret, as a further easement for the customers, controller, and clerks."12 Greater attention to comfort, privacy, and the division of tasks and spaces lies behind the construction of extra chambers and a latrine.

Chaucer himself now lived not in a great household as he had done earlier in his career, but in rooms above Aldgate - although he may have stayed at other locations in London, such as his mother's house. But, interestingly, although for many people, as Sarah Stanbury comments, "privacy was becoming a desirable good," Chaucer seems to have had decidedly mixed feelings about the trend towards more private modes of living. ${ }^{13}$ When he writes about a lightlyfictionalised version of his own room, as a place where "Geffrey" writes poetry in the House of Fame, its privacy is a problem, not a source of creative liberation. This is a poem about writer's block: Geffrey's existence within his private room has been uninspiring. Indeed, when Geffrey reads alone, he "herist nether that ne this" (651): he is deaf to his neighbours. He cannot speak: he is "domb as any stoon" (656). His eyesight is affected: ("fully daswed ys thy look," [658]) and he is like one who is fasting, "a heremyte" (659), although in fact his "abstynence ys lyte" (660). His senses are numbed, and his reading is profitless - he has no tidings, no inspiration, and needs divine help. He ignores the "neyghebores"

\footnotetext{
${ }^{9}$ John Schofield suggests there was a "resurgence of construction" in 1369-83, and also discusses the increasing trend for multi-storey buildings in the late fourteenth century. Medieval London Houses (New Haven: Yale University Press, 2003), 3.

10 Schofield, Medieval London Houses, 93, 70.

${ }^{11}$ Maryanne Kowaleski and P.J.P. Goldberg (eds.), Medieval Domesticity (Cambridge: CUP, 2008), especially Goldberg, "The fashioning of bourgeois domesticity in later medieval England: a material culture perspective," 124-144.

${ }^{12}$ Calendar of the Patent Rolls Preserved in the Public Record Office: Richard II, vol. 2 (London: Eyre and Spottiswoode, 1897), Membrane 20, 143 (July 18 $\left.{ }^{\text {th }}, 1383\right), 299$.

13 Sarah Stanbury, "'Quy la?': The Counting House, the Shipman's Tale, and Architectural Interiors," in Susanna Fein and David Raybin (eds.), Chaucer: Visual Approaches (University Park: Pennsylvania State University Press, 2016), 37-56, 42.
} 
(649) at his "dores" (650), instead of going and listening to their stories. The final scene of the House of Fame reveals that it is only through chaotic, interactive collaboration across the multiple thresholds of a building covered in unguarded openings (1945-1955) that Geffrey can find new tidings, and the promise of a poem. ${ }^{14}$

Throughout his poems, Chaucer frequently suggests that closing oneself into a room is intellectually problematic; that to engage more fully with texts one needs to read them in company with others. The Monk, whom the Host hopes will prove to be a "myghty man," able to act like a "tredefowel," and tell great stories turns out to be quite the opposite: he has been reading hundreds of tragedies "in my celle," and his reading has been sterile (Prologue of the Monk's Tale, 1959, 1945, 1972). He repeats them unprogressively and randomly; his reading is non-generative and fails to engage his audience. In the Shipman's Tale, when the merchant's connection with his account books means that he does not see what is going on under his nose (his friend and wife's adultery), again this is connected with reading alone and with sensual deprivation. He goes to his counting-house and "his countour-dore he shette" (85), cutting himself off so much that his wife has to bang at the door (213). ${ }^{15}$ His isolation is characterized as a fast $(215,222)$ : his wife emphasizes the fact that his privacy with his books is delaying mass and therefore dinner and sensual pleasure (223). This kind of engagement with books is very different from the common medieval scene of listening to a book while eating, a practice that connects books and the body, ingesting knowledge and food together. ${ }^{16}$

In Chaucer's poems, readers have to engage with other minds in order for the reading to be initiatory or productive - to lead to a new text, a new reading, new tidings. We might think, for instance, of the Nun's Priest's Tale, which, as Peter Travis has shown, reprises the experience of the medieval schoolroom, a place of debate for debate's sake, where books are the catalyst for interpretative

\footnotetext{
${ }^{14}$ Excellent recent readings of this extraordinary scene include Ashby Kinch's interpretation of the House of Rumour as an intuitive representation of the neuroplasticity of the brain and Ruth Evans's suggestion that the layering of sources in the memory and the aurality of the House of Rumour preempt the noise and multiplicity of the internet. Ashby Kinch, "'Mind Like Wickerwork": The Neuroplastic Aesthetics of Chaucer's House of Tidings,' postmedieval 3 (2012): 302-14; Ruth Evans, 'Chaucer in Cyberspace: Medieval Technologies of Memory and The House of Fame,' Studies in the Age of Chaucer 23 (2001), 43-69.

15 Stanbury discusses this threshold in "Quy La," 38, 44.

16 Joyce Coleman, Public Reading and the Reading Public in late medieval England and France (Cambridge: CUP, 1996), 82-83 and “Audience," in Marion Turner (ed.), A Handbook of Middle English Studies (Wiley-Blackwell: 2013), 155-169.
} 
games and play. ${ }^{17}$ Even when in bed, wanting to read a book, Chaucer's persona can call out to someone else - a servant, a friend - to bring him his volume of the Metamorphoses (Book of the Duchess, 47-48). One of Chaucer's most famous reading scenes occurs at the beginning of Book II of Troilus and Criseyde, where we see Criseyde and her female relatives and friends reading a romance in a "paved parlour" (82); later, her niece sings a love song in a garden and they discuss its meanings (813-903). As a widow, Criseyde is living in a female community of friends and relatives, able to read and talk about books together (until Pandarus intervenes). ${ }^{18}$ This is the broader intellectual context in which "Geffrey" is encouraged to enter into discussion with his neighbours about stories.

Chaucer's London life was not the life of an anonymous commuter, writing anonymous bureaucratic documents and retreating, unseen and uncared about to his apartment. It was a life of intersecting communities, activities, and politics. Even the mechanics of Chaucer's writing life involved collaboration. Critics have usually assumed that he wrote rough versions of his texts either on wax tablets or on parchment or paper, and then took them to a scribe who made a fair copy. ${ }^{19}$ He must have been well-acquainted with the shops of Paternoster Row, a street directly north of St Paul's churchyard, the centre of the bookmaking trade. ${ }^{20}$ We know that he worked with scribes such as Adam Pynkhurst, who seems to have worked part-time out of the Mercers' base at the Hospital of St Thomas Acon. ${ }^{21}$ We might imagine Chaucer carrying his tablets or papers through the city to his scribes, who took Chaucer's "makyng," and wrote it

\footnotetext{
17 Peter Travis, Disseminal Chaucer: Rereading the Nun's Priest's Tale (Notre Dame: University of Notre Dame Press, 2010), 54-57.

${ }^{18}$ For discussions of the freedoms enjoyed by later medieval women see Helen M. Jewell, Women in Medieval England, Caroline M Barron, "The "Golden Age" of Women in Medieval London," in Medieval Women in Southern England, Reading Medieval Studies XV (1989), 35-58, and Caroline Barron and Anne Sutton eds., Medieval London Widows 1300-1500 (London: 1994).

${ }^{19}$ A. I. Doyle and M. B. Parkes, "The Production of Copies of the Canterbury Tales and the Confessio Amantis in the Early Fifteenth Century", in M. B. Parkes and Andrew G. Watson (eds.), Medieval Scribes, Manuscripts and Libraries: Essays Presented to N. R. Ker (1978), 163-210: 167, Daniel Wakelin, Scribal Correction and Literary Craft: English Manuscripts, 1375-1510 (Cambridge, 2014), 87-94, and Linne R. Mooney, “Chaucer's Scribe”, Speculum, 81 (2006), 121. ${ }^{20}$ C. Paul Christianson, "The Rise of the Book-Trade," in The Cambridge History of the Book in Britain, volume 3, ed. Lotte Hellinga and J. B. Trapp, (Cambridge: CUP, 1999), 128-147, 128-129 and Erik Kwakkel, "Commercial organization and economic innovation," in Alexandra Gillespie and Daniel Wakelin (eds.), The Production of Books in England 1350-1500 (Cambridge, CUP, 2011), 173-190, 181.

${ }^{21}$ Mooney, "Chaucer's Scribe," 111. On Pynkhurst's "shop" see also Alexandra Gillespie, "Books," in Strohm (ed.), Middle English, 86-103, 98-99. Lawrence Warner disputes some of Mooney's findings, but agrees that Pynkhurst worked on Chaucer's texts, specifically a Boece manuscript. Lawrence Warner, 'Scribes, Misattributed: Hoccleve and Pinkhurst,' Studies in the Age of Chaucer 37 (2015): 55-100.
} 
"newe," after which Chaucer himself might have to "correcte," the version ('Chaucers Wordes Unto Adam, His Owne Scriveyn,' 4,2,6). Some of the work might have taken place in Pynkhurst's or Chaucer's homes. ${ }^{22}$ Certainly, the physical production of Chaucer's texts took place neither in large public scriptoria nor in isolation; it usually involved two people (Chaucer and a scribe) who either passed the text back and forth for correction or even partly worked together. Chris Cannon has recently suggested an interestingly interactive model of composition, arguing that Chaucer may have dictated his poems to scribes acting as secretaries, perhaps using a partial copy as a prompt. ${ }^{23}$ In this model, there is no authorial original or stem text; rather, Chaucer kept the text partly in his head and added bits, changed stanzas around, or missed bits out as he reworked the text through multiple dictations. There is no doubt that the production of each text was a social and collaborative enterprise; it may even be the case that the text was partly built through the interactive process of dictation. That does not mean that scribes were creatively involved in the texts (although they might have been at times). ${ }^{24}$

Chaucer imagines the solitary intellectual as "domb as a stone," in the House of Fame; in the Clerk's Prologue and Tale, he takes aim at his predecessor, Petrarch, a scholar known for his separation from social and political life, noting that he is "deed and nayled in his chest" (29). Petrarch argued that intellectuals needed otium (leisure), ideally in settings of rural beauty, where they could cultivate their minds apart from destructive and distracting negotium. He was not arguing for complete isolation; his ideal was to commune with a small group of like-minded, male, intellectual friends. ${ }^{25}$ Chaucer turned his back on the Petrarchan ideal of writing in a peaceful retreat, just as he turned his back on

\footnotetext{
22 Linne R. Mooney, "Locating Scribal Activity in Late Medieval London," in Margaret Connolly and Linne R. Mooney (eds.), Design and Distribution of Late Medieval Manuscripts in England (York: University of York Press, 2008), 183-204.

${ }^{23}$ Christopher Cannon, "Wyth her owen handys": What Women's Literacy Can Teach Us about Langland and Chaucer," Essays in Criticism (2016) 66 (3): 277-300.

${ }^{24}$ Indeed, one of the key aspects of Cannon's argument is that the scribes tended to use final "e"s non-metrically precisely because they were not thinking about Chaucer's poetic metre, but simply using their own spelling practices. Cannon, "Wyth her owen handys," 293-294.

${ }_{25}$ Petrarch wrote two treatises relevant here: De vita solitaria and De otio religiosa. See discussions in Julia Conaway Bondarella, "Petrarch's Rereading of Otium in De Vita Solitaria," Comparative Literature 60:1 (2008), 14-28, Unn Falkeid, "De Vita Solitaria and De Otio Religioso: the Perspective of the Guest," in Albert Russell Ascoli and Unn Falkeid (eds.), The Cambridge Companion to Petrarch (Cambridge: CUP, 2015), 111-119; Susanna Barsella, "A Humanistic Approach to Religious Solitude," in Victoria Kirkham and Armando Maggi (eds.) Petrarch: A Critical Guide to the Complete Works (Chicago: University of Chicago Press, 2009), 197-208 ; and Armanda Maggi, "You Will be My Solitude': Solitude as Prophecy (De Vita Solitaria)," in Petrarch: A Critical Guide, 179-195.
} 
Petrarch's self-aggrandizement, his gender politics, and his collusion with an absolutist regime. ${ }^{26}$ Instead, Chaucer ultimately chose a Southwark inn as his cultural home. ${ }^{27}$ Like Boccaccio, and unlike Petrarch, Chaucer imagined an audience that was mixed in gender and varied in social degree, and his work seems always to have been produced in the midst of, not separated from, the negotium of his life. ${ }^{28}$ Interestingly, one of the neighbours living almost at Chaucer's door in London was his daughter, who herself inhabited a surprisingly accessible space - a nunnery.

\section{Chaucer's Daughter}

Thinking about the porous spaces of Chaucer's London leads me to this final space, an institution which we might expect to be locked and enclosed: the nunnery in which Elizabeth Chaucer lived. ${ }^{29}$ She is very little discussed, although she lived round the corner from the poet for several of his Aldgate years. The kinds of rooms that she lived in, and the economics of the nunnery of which she was a part are significant for thinking about the status, lifestyle, and opportunities for elite women in the later fourteenth century. Elizabeth and women like her were, in fact, able to live fairly free lives, both economically and intellectually, but not because they had rooms of their own with locked doors. On the contrary, their lives were embedded in their local communities, and the spaces they lived in demonstrate that even spaces that were "supposed" to be enclosed were in fact far more open to the world than we might expect.

Elizabeth's home was, presumably, another node in Chaucer's London itineraries, another space that he visited, along with the Customs' House, St Thomas of Acon, or his mother's house.

Three years after Chaucer started work at the Customs House, Elizabeth became a nun at St Helen's Bishopsgate, less than a third of a mile - a five-minute

\footnotetext{
26 On Chaucer and Petrarch see David Wallace, Chaucerian Polity: Absolutist Lineages and Associational Forms in England and Italy (Stanford: Stanford University Press, 1997), esp. 261298.

27 On the circulation of Troilus in Southwark taverns see Martha Carlin, "Thomas Spencer, Southwark Scrivener (d. 1428): Owner of a Copy of Chaucer's Troilus in 1394?" Chaucer Review 49: 4 (2015): 387-401. See also Sebastian Sobecki, "A Southwark Tale: Gower, the 1381 Poll Tax and Chaucer's The Canterbury Tales," Speculum 92:3 (2017): 630-660.

${ }^{28}$ Petrarch comments (disparagingly) in a letter to Boccaccio that he had clearly written the Decameron for the multitude. See discussion in Wallace, Chaucerian Polity, chapter 10. On Boccaccio's mercantile environment and audience, see Vittore Branca, Boccaccio: The Man and His Works, trans. Richard Monges (New York: Harvester Press, 1976), especially 276-297.

${ }^{29}$ For Chaucer's sister see Martin M. Crow and Clair C. Olson, Chaucer Life-Records (Oxford: OUP, 1966), 288-289.
} 
walk - from Chaucer's rooms. The evidence comes from the Patent Rolls. In 1377, when Richard II took the throne, he exercised a royal prerogative to nominate two girls to become nuns at prestigious nunneries: one at Barking Abbey, an exceptionally wealthy and aristocratic house, the other at St Helen's Bishopsgate, also a rich foundation, albeit a notch under Barking, and unusual in having strong mercantile, city connections. ${ }^{30}$ This was the only time that a monarch ever exercised this alleged prerogative in relation to St Helen's, so it may have been invented for the occasion. Richard was ten years old and his uncle, John of Gaunt, was directing affairs, so it is clear that Gaunt was very keen to place these girls in comfortable and indeed fashionable surroundings. The girl nominated to Barking on July 27th 1377 , was Margaret Swynford, daughter (by her first marriage) of Katherine, now Gaunt's beloved mistress and mother of his own children. Elizabeth Chaucer (niece of Katherine and therefore first cousin to Margaret, and herself the daughter of the poet and Philippa Chaucer, lady in waiting to Gaunt's wife, Constance) was the girl nominated to St Helen's Bishopsgate. We know nothing of Elizabeth prior to this point; it is most likely that she was born around the mid-late 1360s and was between about 8 and $12 .{ }^{31}$ Margaret was a similar age. This was very young to become a nun, but not unheard-of, and there were other children in nunneries as lodgers and pupils, so a child-nun would not be isolated. ${ }^{32}$ The records do make it clear that Elizabeth is entering St Helen's as a nun, not as a student herself. ${ }^{33}$ In some ways, though, entering into the priory at this time would have been fairly similar to entering into a great household, in terms of the standard of living, educational opportunities, and social interactions available.

Nunneries were an essential part of the social fabric, not places of removal and separation. They were businesses: they owned land and other property, collected rents, went to court. ${ }^{34}$ Far from being separated from others, the nuns in these religious houses were outnumbered two to one by lodgers,

\footnotetext{
${ }^{30}$ For the nominations, see Calendar of Patent Rolls Preserved in the Public Record Office: Richard $I I$, vol. 1, p. 20; entry for July 27th 1377 . For the wealth of Barking and St Helen's, usefully set in the context of the wealth of 61 nunneries, see Roberta Gilchrist, Gender and Material Culture: The Archaeology of Religious Women (London and New York: Routledge, 1994), 129-130.

31 We first hear of Geoffrey and Philippa being married in 1366 although the marriage could have taken place earlier. Katherine married Sir Hugh Swynford at a similar time and he died in 1371.

32 Paul Lee, Nunneries, Learning, and Spirituality in Late Medieval English Society: The Dominican Priory of Dartford (York: York University Press, 2001), 160-162; Eileen Power, Medieval English Nunneries c. 1275-1535.

33 Calendar of Patent Rolls Preserved in the Public Record Office: Richard II, p.20.

${ }^{34}$ Nancy Bradley Warren, Spiritual Economies: Female Monasticism in Later Medieval England (Philadelphia: University of Pennsylvania Press, 2001), 67; Lee, Nunneries, 50-51.
} 
servants, and other lay members of the household. ${ }^{35}$ Within such houses, important nuns occupied private sets of chambers and ate luxurious food. ${ }^{36}$ This does not mean that the nuns were irreligious, or that prayer was unimportant; but it demonstrates that nuns, who came from wealthy backgrounds, maintained their standard of living once they entered the cloister. Indeed, within nunneries, there was a developing trend for more private modes of living, a trend that mirrors lifestyle changes in secular life too and that was a source of anxiety. In 1387, for instance, William of Wykeham sent injunctions to the nunneries under his diocesan control, exhorting the nuns to eat communally and warning them against holding private property. ${ }^{37}$

Chaucer surely visited his daughter; her placement in St Helen's makes particular sense if we remember that her father was living very close by, and indeed her grandmother, Chaucer's mother, also lived in the city. And St Helen's was a welcoming place for visitors. Sixty years later, Dean Reynold Kentwode visited St Helen's and wrote detailed recommendations for reform. The practices that he describes and prohibits were clearly entrenched, so his injunctions give us an insight into what this house was like when Chaucer's daughter was there. Kentwode writes that "there is moche coming in and owte unlefulle tymys," and urges the nuns not to allow a secular visitor to "be lokkyd withinne the boundes of the cloystere," nor to come in after compline, except for women servants and girl pupils. The prioress is urged to sleep in her "dortour" by night and the nuns should refrain from "daunsyng and revelyng" except at Christmas and other "honest tymys of recreacyone." 38 The specific spaces of the priory are a constant concern for Kentwode. He frequently worries about who is inside "the boundes", advising on what kind of person should be in charge of the keys (a "sadde woman and discrete"), and ordering that the nuns should not be able to unlock the postern door and get into the churchyard. He also makes specific recommendations about changing the way the church and its outbuildings are divided, which lets us know their prior layout. For instance, Kentwode wants a

\footnotetext{
35 Warren, Spiritual Economies, 66.

${ }^{36}$ On private quarters and eating see Marilyn Oliva, The Convent and the Community in Late Medieval England: Female Monasteries in the Diocese of Norwich 1350-1540 (Cambridge: Boydell Press, 1998), 102-103 n. 171; on the diet at Barking see "Charthe longynge to the Office of the Celeresse of the Monasterye of Barkynge," in William Dugdale, Monasticon Anglicanum 6 vols. (London: Longman, 1817-30), I: 442-445.

37 Richard Luce (ed. and trans.), "Injunctions Made and Issued to the Abbess and Convent of the Monastery of Romsey After His Visitation By William of Wykeham, 1387," in Hampshire Field Club and Archaeology Society Proceedings 17 pt 1 (1949), 31-44, 34, 38.

${ }^{38}$ Reynold Kentwode's injunctions date from $21^{\text {st }}$ June 1439. Dugdale, Monasticon, IV: 553-554.
} 
door to be built on the "Nonnes Quere" - the nuns' part of the double church, which was half the nuns' place of worship (the north side), and half a parish church (the south side), the two halves placed side-by-side. Kentwode's injunction suggests that the two halves were not firmly separated and indeed he specifies that the door should be provided so that strangers don't look at nuns, nor nuns at strangers. Even more intriguingly, he wants the prioress to make "a hache of conabyll heythe, crestyd withe pykys of herne to fore the entre of yowre kechyne" to keep "straunge pepille" out. He here specifies that the kitchen should be closed off with a door - perhaps a split stable-type door - with horned spikes on the top. The symbolism of the "pykys of herne" is fascinating: presumably these would be aesthetically impressive and also intimidating. Is the idea partly that the spikes would discourage people from climbing in? In which case, were there people that did indeed want to climb into - or out of - the priory? There are cases of nuns running away and marrying. ${ }^{39}$ The detail that Kentwode supplies reveals how much patterns of behavior are perceived as being tied to the arrangement of space. The fortified door is to be a guarantee of the nuns' morality; a more complete enclosure will protect them from the moral infections and physical incursions of the secular world. St Helen's social and spatial practices were typical: Wykeham's injunctions to Romsey Abbey issued in 1387 similarly complain about, "the great traffic and concourse of secular people of either sex through your cloister," and go on to lay down rules about when doors can and cannot be opened, and about who should have guardianship of the doors. ${ }^{40}$

Elizabeth only stayed at St Helen's for four years. In 1381, she transferred to Barking Abbey, where her cousin already lived. John of Gaunt paid lavishly for this transfer: he expended $£ 51,8 \mathrm{~s}, 2 \mathrm{~d} .{ }^{41}$ She was still there in 1397 and presumably stayed there until her death. But why did Elizabeth move in 1381 ? Gaunt issued the warrant for the payment on 12 May - i.e. before the Great Revolt, so the horror of the rebels' behavior in London was not a factor. Instead, I would tentatively point to another document: Chaucer's quitclaim of the property in Vintry Ward, on 19 June, 1381.42 This quitclaim reveals to us that

\footnotetext{
${ }^{39}$ Minnie Reddan and Alfred W. Clapham, The Parish of St Helen Bishopsgate in Survey of London vol. IX (London: London County Council, B.T. Batsford, 1924), 8.

${ }^{40}$ Luce, "Injunctions," 41.

${ }^{41}$ Chaucer Life-Records, 546.

${ }^{42}$ Chaucer Life-Records, 1-2. See p.10 and p.10 n.1 for Agnes Chaucer and Bartholomew Chappell's possession of the property after John Chaucer's death.
} 
Chaucer's mother had died. She had previously owned this property, after the death of John Chaucer, and Chaucer inherited it from her, not from his father. As this is the first reference to the property being in Chaucer's ownership it is reasonable to assume that she died not long before this date and that Chaucer immediately, or fairly quickly, handed it over to the long-term tenant, Henry Herbury. Elizabeth, a child in London, very probably saw her grandmother regularly and her death might have made London a much lonelier place for her notwithstanding the presence of her father. Her move to Barking might then have been strongly motivated by the desirability of being near another female relative (her cousin Margaret) now that she no longer had her grandmother to support her. These two privileged women were, in many ways, more independent than married women, able to live comfortable and intellectually free lives, lives of figs and books. ${ }^{43}$ Margaret, indeed, became the Abbess at Barking, which meant becoming a major businesswoman and manager. Just as Geffrey needs to go to his doorway and engage with his neighbours, Elizabeth probably wanted to have access to her female relatives, outside or within the nunnery itself. Sociability and interaction mattered more than separation or isolation.

The London life that Chaucer knew was a life of contact, connection, and above all, collaboration. The threshold of Geffrey's room in the House of Fame, Criseyde's garden in Troilus and Criseyde, or the book-lined henhouse in the Nun's Priest's Tale are all imagined as semi-public, semi-private spaces where people can talk about books and stories. These spaces are partially enclosed but not locked and they imaginatively mirror rooms and institutions - such as St Helen's Bishopsgate - in contemporary London. The porous spaces and unlocked rooms of the city facilitated the conversations with those "neyghebores / That duellen almost at thy dores" (649-650) that enabled creative production. Chaucer was profoundly suspicious of the benefits of a room of one's own and a lock on the door.

43 "Charthe," in Dugdale, Monasticon, I: 444. 